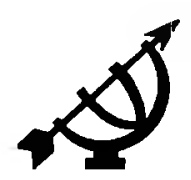

\title{
Geregtigheid, billikheid en waarheid in Platoniese en hedendaagse perspektief: Antieke waardes in Suid-Afrikaanse konteks
}

\author{
Deon van Zyl S.C. 1 \\ Fakulteit Regte \\ Potchefstroomse Universiteit vir $\mathrm{CHO}$ \\ POTCHEFSTROOM \\ E-pos: dhvanzyl@isales.co.za
}

\begin{abstract}
Justice, faimess and truth in Platonic and contemporary perspective: ancient values in South African context

The concept of justice (dikaiosyne) in the thought of Plato was only one of the four cardinal virtues described by him, the others being wisdom (sophia), restraint (sophrosyne) and courage (andreia). Justice was inevitably linked with fairness or equity (epieikeia), a concept more fully developed by Plato's most famous pupil, Aristotle. It was likewise associated with the concept of truth (aletheia) as a virtue and as part of a purifying process. Later generations of philosophers, from Cicero to Rawls, were fascinated by such Platonic and Aristotelian thought, although they interpreted it in various ways. In a changing world many ancient values are as relevant today as they were in the distant past. They are basic to fundamental human rights, which have become so prominent in modern times. They are essential ingredients of peace and reconciliation, as amply recognised in South Africa, which has only recently joined the community of democratic nations and is dependent on instruments, such as its new Bill of Rights and the Truth and Reconciliation Commission, to achieve transformation.
\end{abstract}

\section{Inleiding}

Dit is vir my 'n besondere eer en voorreg om 'n bydrae te kan lewer in 'n feesbundel wat aan Johan van der Vyver opgedra word. Oor baie jare heen was

1 Regter Deon H. van Zyl is 'n ereprofessor in die Fakulteit Regte (PU vir CHO), regter van die Kaapse Hooggeregshof, buitengewone professor in Regte (Universiteit van die Vrystaat) en besoekende professor (Universiteit van Edinburgh). 
hy nie net 'n vriend nie, maar ook 'n mentor en akademiese rolmodel. In 'n tyd toe dit ongewild was om menseregte en "liberale" waardes voor te staan, het hy op onverskrokke en merkwaardig individualistiese wyse sy diepe agting vir die onaantasbare waardigheid van alle mense uitgeleef. Watter aanwins sou hy nie gewees het vir ons Konstitusionele Hof nie. Watter verlies vir ons dat hy hom genoop gevoel het om sy werk voort te sit in die VSA, waar hy ruimskoots die eer en erkenning ontvang wat hom toekom.

Die onderwerp van hierdie bydrae het ontstaan uit 'n lesing wat ek aangebied het by 'n seminaar oor "The immediate relevance of the Platonic virtues in our society", gereël deur die School of Practical Philosophy te Johannesburg gedurende Maart 1998. Vir die doeleindes van 'n huldigingsbundel aan Johan, het ek gedink dat dit 'n interessante oefening sou wees om te kyk in hoeverre daar raakpunte bestaan tussen die antieke waardes van Plato en die waardes waarop ons huidige konstitusionele bedeling gegrondves is. Tyd het ongelukkig ontbreek om 'n meer diepgaande studie oor die onderwerp aan te pak.

\section{Geregtigheid, biiiikheid en waarheid by Plato}

Plato se leerstellings kan nie na behore begryp word indien daar nie van sy verhouding met sy leermeester, Sokrates, kennis geneem word nie. Want dit was juis Sokrates wat as stimulus gedien het vir Plato se denke en vir die ontwikkeling van sy oorweldigende wysheid.

\subsection{Sokrates se invloed}

Sokrates (c 469-399 v.C.) was sekerlik een van die briljantste filosowe wat deur antieke Griekeland opgelewer is. Dit is merkwaardig dat hy sy wysgerige kennis uitsluitlik mondeling, deur middel van gesprek oftewel dialektiek, aan sy studente oorgedra het en self niks daarvan op skrif gestel het nie. Sy denke is egter verewig deur die werke van sy studente, op wie hy kennelik 'n onuitwisbare indruk moes gemaak het.

Die sentrale tema wat Sokrates se lewensbenadering versinnebeeld het, was dié van "ken jouself" (gnothi seauton). Deur jouself te ken, sou jy kennis kon opdoen van die twee basiese vooropstellings wat ware geluk en welvaart (eudaimonia) meebring, naamlik die beginsel om nooit enige kwaad te doen of om enigsins daarby betrokke te raak nie, en die besef dat ware kennis van wat reg, regverdig en goed is, dit onmoontlik maak om strydig daarmee op te tree Dit het ook saamgehang met sy beklemtoning van die versorging van die siel (psyche) as die setel van die intellek, wat beheer uitoefen oor 'n mens se persoonlikheid, sin vir verantwoordelikheid en morele waardeoordele. Dit is juis die siel waarin deug of deugsaamheid (arete), in die sin van kennis van wat moreel goed is, sy beslag gekry het 
Oor die onderwerp van geregtigheid het Sokrates geleer dat dit vir alle mense dieselfde is en dus universeel geld as uitdrukking van die ingebore en diep penetrerende aard daarvan. Hoewel dit in wese neerkom op 'n natuurregteorie, het hy steeds sy eerbied vir die positiewe reg gehandhaaf, soos blyk uit sy gewilligheid om eerder die doodstraf te aanvaar, al was die aanklagte teen hom versonne en absurd, as om van politieke of ander middele gebruik te maak om dit te ontkom (Van Zyl, 1991b:19-20 en die gesag aldaar aangehaal).

\subsection{Plato: opleiding en vorming}

In die voorste linie van Sokrates se studente was Plato (427-347 v.C.), wie se uitgebreide werke, gekenmerk deur hulle hoogstaande gehalte, hom een van die heel grootste van alle Westerse filosowe gemaak het (Van Zyl, 1991b:21-22, met verwysing, onder andere, na die klassieke werk oor die verhouding tussen Sokrates en Plato, naamlik Field, 1913). Dit is nie vreemd nie dat sy diep oorwoë bepeinsing oor uiteenlopende onderwerpe ten grondslag lê van 'n veeltal moderne filosofiese denkrigtings.

Die groot eerbied wat Plato vir Sokrates gehad het, blyk uit die feit dat hy sy leermeester telkens as hoofrolspeler in sy werke laat optree het. Na Athene se neerlaag in die Peloponnesiese oorlog en die daaropvolgende onderdrukkende oligargie onder leiding van Kritias, het Plato egter al hoe meer mismoedig begin raak. Die herstel van demokrasie in 399 v.C. het saamgeval met Sokrates se tragiese dood en Plato het hom genoop gevoel om uitgebreide studiereise te onderneem na lande soos Egipte, Sirene, Suid-Italië en Sicilië, waar hy met verskeie filosofiese skole, insluitende die Pythagoriese, kennis gemaak het. Dit het aanleiding gegee tot sy teorie dat die politiek sou verbeter slegs indien heersers (archontes) filosowe sou word of filosowe (philosophoi) heersers sou word.

\subsection{Plato se Akademie}

Toe hy in 387 v.C. terugkeer na Athene, het Plato sy beroemde Akademie tot stand gebring. Hoewel hy steeds sterk tekens van beinnvloeding deur Sokrates getoon het, het hy geleidelik sy eie unieke denkrigtings begin ontwikkel. Waar Sokrates, byvoorbeeld, geleer het dat kennis van morele goedheid 'n mens daartoe in staat stel om ware deugsaamheid te bereik, het Plato gepoog om die aard van die goedheid te bepaal en om die werksaamheid van die gees, waaruit deugsaamheid ontspring, vas te stel. In hierdie verband het hy onderskei tussen dit wat met die sintuie waarneembaar is (phaenomena) en idees of "vorms" (ideai of eide) wat slegs deur die intellek waargeneem kan word. Laasgenoemde is ewigdurend en absoluut, synde afkomstig van dit wat "goed" (kalon) is. Slegs wanneer 'n mens "ware kennis" (episteme of gnosis) in pag het, kan jy van sodanige idees en vorms bewus raak. 


\subsection{Die kardinale deugde}

Die idees of vorms kan, volgens Plato, in enige gedaante voorkom, hetsy konkreet of abstrak, fisies of psigies. Dit sluit in begrippe soos die "kardinale" of hoofdeugde (in Engels weergegee as "cardinal virtues"), naamlik wysheid (sophia) of verstandigheid (phronesis), geregtigheid (dikaiosyne), moed of dapperheid (andreia) en gematigdheid of selfbeheersing (sophrosyne). Dit is opvallend dat geregtigheid in hierdie verband as "filosofiese" deug figureer, en dan nie eers as die primêre deug nie! Geregtigheid moet sy plek inneem ná wysheid of verstandigheid en vóór moed en matigheid.

Hoewel Plato dit nie in soveel woorde sê nie, is dit duidelik dat hy van leiers in die gemeenskap verwag om oor hierdie deugde te beskik en om dit in hulle daaglikse bedrywighede toe te pas. In moderne konteks sou dit, byvoorbeeld, beteken dat 'n regter geregtigheid kan nastreef slegs indien hy sy funksie met sowel wysheid as verstandigheid sou uitoefen. Daarbenewens verg sy onafhanklikheid en onpartydigheid dat hy vreesloos en met moed of dapperheid optree, terwyl hy voordurend matigheid en selfbeheersing voor oe hou. Dit behoef geen betoog dat dit wat in Plato se tyd gegeld het, eweseer vandag geld.

Kennis van hierdie deugde en ander idees kan bekom word slegs deur die siel of gees (psyche), wat ooreenkomstig Plato se leerstellings bestaan uit die redelike deel (logistikon), die emosionele deel (thymoeides) en die begerende deel (eptthymetikon), wat onderskeidelik in die hoof, die bors en die maag geleë is! Dit korrespondeer met die drieledige indeling van die ideale staat: die heersers en filosowe verteenwoordig die redelike, die soldate en bewaarders van die staat die emosionele en die gewone burgers die begerende aspek van die gees. Met verwysing na die kardinale deugde, beskik die eerste groep oor wysheid en verstandigheid, die tweede groep oor moed en dapperheid en die derde groep oor gematigdheid en selfbeheersing. Die deug van geregtigheid word nie aan enige van hierdie groepe toegedeel nie, aangesien Plato dit beskou as 'n oorkoepelende deug wat die ideale staat as geheel simboliseer.

\subsection{Plato se geregtigheidsbegrip}

Plato se geregtigheidsbegrip word op verskeie plekke in sy werke aangetref, maar dit kom meer in die besonder voor in sy verhandelinge oor die Republiek (Politiea) en die Wette (Nomoi). Die eerste boek van die Politeia is in werklikheid 'n dialoog oor geregtigheid, terwyl die oorblywende nege boeke gewy word aan die begrip van 'n ideale staat. In die Nomoi verduidelik Plato weer hoe die ideale staat behoort te funksioneer, met behulp van 'n kodifikasie van hoogs morele wette wat streng nagekom moet word

Geregtigheid word in die Politeia voorgestel as een van die grondliggende ideale van kennis en deugsaamheid. Dit is juis die deug wat vereis word vir die suksesvolle funksionering van die ideale staat wat daarop ingestel is om chaos 
en ongeregtigheid in die wêreld te beëindig en dit met 'n gees van orde en redelikheid te vervang. Hierdie gedagte sluit aan by Plato se voorstelling van 'n goddelike skepper van wette en geregtigheid soos ons dit vind in die Nomoi. Wette moet juis van nature bevorderlik wees vir die daarstelling van 'n deugsame lewenspatroon onder diegene wat daardeur geraak word.

\subsection{Die aard van geregtigheid teenoor ongeregtigheid}

Dit is moeilik om ' $n$ definisie van geregtigheid as sodanig in Plato se geskrifte te vind. 'n Prikkelende passasie uit die Politeia (335 B-E), waarin Sokrates met ene Polemarchus 'n gesprek voer, wys egter op die aard van geregtigheid as 'n deug en bring dit in verband met uitnemendheid by mense en diere, soos blyk uit die vertaling van Michael Arnheim (Arnheim, 1977:173-174):

'Is it really", said I [d.w.s. Sokrates], 'fitting for a just [dikaios] man to harm any other person at all?' 'Of course it is', said he [d.w.s. Polemarchus]. 'One ought to harm bad men who are one's enemies'. 'When horses are harmed do they become better or worse?' 'Worse'. 'In regard to the excellence [arete] of dogs, or that of horses?' 'In regard to that of horses'. 'And so, when dogs are harmed do they become worse in regard to the excellence of dogs and not of horses?' 'Of course'. Should we not then speak in the same way of men, my friend, who when harmed become worse in regard to human excellence?' Yes, certainly'. 'But is not justice [dikaiosyne] the specifically human excellence [arete]?' 'Of course'. 'So it necessarily follows, my friend, that those men who are harmed become more unjust'. 'So it would seem'. 'But can musicians make people unmusical by means of music?' 'No'. 'And can riding masters make people unskilled in riding by means of horsemanship?' 'Not at all'. 'So, can the just make men unjust through the exercise of justice? Or, in short, can the good make people bad through virtue [arete]?' 'It is impossible'. 'For it is not, I think, the function of heat, but of its opposite, to cool'. 'Indeed'. 'Nor of dryness, but of its opposite, to moisten'. 'Certainly'. 'Nor of the good, but of its opposite, to harm'. 'So it will appear'. 'But the just man is good?' 'Certainly'. 'It is not then the function of a good man to harm anyone, Polemarchus, whether a friend or anyone else, but that is the function of his opposite, the unjust man'. 'I think, Socrates', said he, 'that what you say is absolutely true'. 'If, therefore, anyone says that it is just to give each man his due and understands by this that what is due to his enemies from the just man is harm and to his friends advantage, he is not a wise man to say so, for he would not be speaking the truth. For it has become clear to us that it is never just to harm anyone'.

Dit blyk hieruit dat Plato die aard van geregtigheid evalueer aan die hand van 'n vergelyking tussen reg en onreg, oftewel geregtigheid (dikaiosyne) en ongeregtigheid (adikia). Dit word mooi geillustreer in 'n debat wat Sokrates voer met ene Thrasymachus, wat beweer het dat "volmaakte en volledige ongeregtigheid meer voordelig is as volledige geregtigheid", in die sin dat "ongeregtigheid betaal terwyl geregtigheid nie betaal nie" (Politiea $348 \mathrm{~B}-\mathrm{C}$ ) 
Hy gee egter toe dat 'n regverdige man nie 'n ander regverdige man sou wou uitoorlê nie, hoewel hy dit miskien sou wou doen in die geval van 'n ander onregverdige man. Aan die ander kant sou 'n onregverdige man nie huiwer om 'n ander onregverdige man te uitoorlê met die oog daarop om die maksimum wins vir homself te bekom nie (Politeia 349 B-C).

Dit gee aanleiding tot 'n verdere toegewing, naamlik dat 'n onkundige man 'n wyse man sou uitoorlê met dieselfde gemak as wat hy dit aan 'n ander onkundige man sou doen. In so 'n geval is die onkundige onregverdig en die wyse regverdig. Dit beteken dan dat geregtigheid (dikaiosyne) 'n deug (arete) is en 'n kenmerk van wysheid (sophia), terwyl ongeregtigheid (adikia) 'n euwel (kakia) is wat deur onkunde (amathia) gekenmerk word (Politeia $350 \mathrm{~B}-\mathrm{D}$ ).

Thrasymachus se voormelde bewering word op hierdie wyse betekenisloos, soos blyk uit die volgende retoriese vraag en antwoord wat Plato aan Sokrates toeskryf (Politeia 351 A: vertaling van Shorey, 1969:95):

'This, then, is the question I ask, the same as before, so that our enquiry may proceed in sequence. What is the nature of injustice as compared with justice? For the statement made, I believe, was that injustice was a more potent and stronger thing than justice. But now', I said, 'if justice is wisdom and a virtue, it will easily, I take it, be shown to be also a stronger thing than injustice, since injustice is ignorance ...'

In die voortsetting van sy debat oor die aard van geregtigheid doen Plato, deur Sokrates, aan die hand dat regverdiges 'n beter en gelukkiger lewe voer as onregverdiges, wat ' $n$ bewys is dat geregtigheid meer voordelig is as ongeregtigheid (Politeia $352 \mathrm{D}-354 \mathrm{~A}$ ).

\subsection{Universele en individuele geregtigheid}

Plato onderskei tussen wat hy noem "universele geregtigheid" en "individuele geregtigheid". Eersgenoemde slaan in wese op geregtigheid in staatsverband terwyl laasgenoemde betrekking het op geregtigheid tussen individuele burgers. Die onderskeid word verduidelik aan die hand van 'n gesprek tussen Socrates en ene Glaukon (Politeia 433 A-C: vertaling van Shorey, 1969:367-369):

'Listen then', said I, 'and learn if there is anything in what I say. For what we laid down in the beginning as a universal requirement when we were founding our city, this, I think, or some form of this, is justice [dikaiosyne]. And what we did lay down, and often said, if you recall, was that each one man must perform one social service in the state for which his nature was best adapted'. 'Yes, we said that'. 'And again that to do one's business and not to be a busybody is justice, is a saying that we have heard from many and have very often repeated ourselves'. 'We have'. 'This then', I said, 'my friend, if taken in a certain sense appears to be justice, this principle of doing one's own business. Do you know whence I infer this?' 'No, but tell me', he said. 'I think that this is the remaining virtue in the state after our consideration of soberness 
[sophrosyne], courage [andreia] and intelligence [phronesis], a quality which made it impossible for them all to grow up in the body politic and which, when they have sprung up, preserves them as long as it is present. And I hardly need to remind you that we said that justice would be the residue after we had found the other three'.

Hieruit blyk dit dat universele geregtigheid slaan op die "morele verpligting" van elke burger om, ten behoewe van die staat, die een of ander bepaalde diens te lewer ooreenkomstig sy talente en bekwaamhede. Die diens is van 'n beperkte aard en onnodige bemoeienis word nie verwelkom nie. Dit word net verwag dat die betrokke diens in die gees van die kardinale deugde gelewer moet word.

Die aard en omvang van individuele geregtigheid blyk weer uit die volgende gesprek tussen Sokrates en Glaukon (Politeia $441 \mathrm{C}-\mathrm{E}$ : vertaling van Shorey, 1969:4-5-407):

'Through these waters, then', said I, 'we have with difficulty made our way and we are fairly agreed that the same kinds equal in number are to be found in the state and in the soul of each one of us'. 'That is so'. 'Then does not the necessity of our former postulate immediately follow, that as and whereby the state was wise so and thereby is the individual wise?' 'Surely'. 'And so whereby and as the individual is brave, thereby and so is the state brave, and that both shall have all the other constituents of virtue in the same way?' 'Necessarily'. 'Just so, then, Glaucon, I presume we shall say a man is just in the same way in which a city was just'. 'That too is quite inevitable'. 'But we surely cannot have forgotten this, that the state was just by reason of each of the three classes found in it fulfilling its own function'. 'I don't think we have forgotten', he said. 'We must remember, then, that each of us also in whom the several parts within him perform each their own task - he will be a just man and one who minds his own affair'.

Uit hierdie gesprek wil dit nie voorkom of daar enige wesenlike verskil tussen universele en individuele geregtigheid bestaan nie. Dit kom daarop neer dat elke individu sy eie sake moet behartig, met inagneming van die deugde van wysheid (verstandigheid), moed en matigheid. Wanneer hierdie deugde met mekaar in ewewig en harmonie verkeer, sal geregtigheid aanwesig wees in sy oorkoepelende hoedanigheid. Jones (1956:3-4) het hierdie ewewigtige harmonie op treffende wyse uitgewys in sy opsomming van die aard van Platoniese geregtigheid:

Plato believed that justice might be self-regarding in so far as it was identical with harmony in the human soul, putting an end to "inner faction, enmity and discord within the self'. If justice is harmony, or something which produces and maintains harmony, it implies a community or reciprocity of forces. In its widest sense, then, as used by Plato, justice represents such a balance of influences within a man's soul as makes for goodness; it becomes roughly synonymous with self-control or temperance, embracing all with which a man of virtue can be concerned, and possession of such practical good sense or prudence as is indispensable for the smooth working of any organized complex 


\section{Geregtigheld, billikheid en waarheid in Platoniese en hedendaagse perspektief}

of relationships, whether the individual human personality, the family, or the city. But in any of its forms justice to Plato was impossible to conceive apart from goodness and wisdom; indeed it was the same thing as virtue which was the only true wisdom; and since the virtuous man was the happy man, it was happiness as well ...

\subsection{Plato se biiilikheidsbegrip}

Die billikheidsbegrip word nêrens in Plato se werke as sodanig omskryf nie. Tog is dit uit sy volledige bespreking van geregtigheid duidelik dat billikheidsoorwegings voortdurend 'n rol speel, al is dit slegs by wyse van afleiding (Van $\mathrm{Zyl}, 1991 \mathrm{~b}: 93-98$ ). Wanneer ook al hy aan geregtigheid inhoud gee, is dit op die grondslag van billikheid teenoor die staat, die individu en medeburgers. Dieselfde geld wanneer hy sy kritiese ingesteldheid teenoor streng bepalings van die wettereg ten toon stel. Sy benadering in hierdie verband het juis aan sy bekendste leerling, Aristoteles (384-322 v.C.), die geleentheid gebied om die begrip billikheid (epieikeia) te ontwikkel en uit te bou.

\subsection{Assosiasie met waaheid}

Dat geregtigheid (saam met billikheid) een van die vernaamste deugde was, staan teen hierdie tyd vas. Dat dit ook ten nouste gekoppel word aan die waarheid (aletheia), blyk uit verskeie passasies in Plato se menigvuldige werke. Ek wil graag verwys na twee daarvan wat verskyn in nie-juridiese werke. Die eerste word aangetref in die Apologie van Sokrates (Apologia Sokratous D 18 par. 1: my vertaling):

... En voorts, manne van Athene, versoek ek u dringend om nie verras te wees of beswaar te maak nie indien u hoor dat ek myself verweer met dieselfde woorde as dié wat ek gewoond was om aan te wend op die markplein, by die bankiers se tafels, waar baie van u my reeds aangehoor het, of elders. Want die feit is dat dit die eerste keer is dat ek voor die hof verskyn, al is ek reeds sewentig jaar oud. Ek is dus ' $n$ totale vreemdeling met betrekking tot die wyse waarop daar hier gepraat word. En daarom, net soos a my natuurlik sou vergewe, indien ek regtig 'n vreemdeling sou wees, indien ek sou praat in die dialek en op die wyse waarop ek groot gemaak is, rig ek nou hierdie versoek aan u, 'n billike versoek, soos dit vir my voorkom, dat $u$ nie ag slaan op my manier van praat nie - want dit sou miskien slegter of beter kon wees - maar dat $u$ waarneem en aandag gee slegs hieraan, naamlik of dit wat ek sê regverdig is of nie. Want dit is die deug van 'n regter, terwyl 'n redenaar se deug is om die waarheid te praat.

Die volgende passasie kom voor in Plato se Phaidon (B 69 par. 13: my vertaling):

... My liewe Simmias, ek vermoed dat hierdie nie die regte manier is om deug te koop nie, deur plesiere vir plesiere te vernuil, en pyne vir pyne, en vrees vir vrees, en meer vir minder, as of dit muntstukke was. Want die enigste aanvaarbare muntstelsel waardeur al daardie dinge vemuil moet word en deur 
middel waarvan al hierdie dinge gekoop en verkoop moet word, is, in werklikheid, wysheid, moed, selfbeheersing en geregtigheid. Kortom, ware deug bestaan slegs tesame met wysheid, ongeag of genietinge en vrese en ander soortgelyke sake toegevoeg of weggeneem sou word. En deug wat, sonder wysheid, bloot bestaan uit die onderlinge uitruil van sulke goed, is maar 'n opgesmukte nabootsing van deug. Dit is in werklikheid slaafs en bevat niks wat gesond of waar is nie. Waarheid is inderdaad 'n suiwering van al hierdie dinge terwyl selfbeheersing, geregtigheid, moed en wysheid op sigself 'n soort suiwering is.

Afgesien van die aangrypende wyse waarop Sokrates se hoftoespraak deur Plato in die Apologie-passasie weergegee word, is dit opvallend dat hy die deugsaamheid van 'n regter met sy versoek om 'n billike verhoor in verband bring, terwyl hy die redenaar se deugsaamheid koppel aan die voordrag van die waarheid. In die passasie uit die Phaidon word die waarheid weer gesien as deel van 'n suiweringsproses, waarvan die kardinale deugde, naamlik wysheid, geregtigheid, moed en selfbeheersing of matigheid, as bestanddele dien. Deugsaamheid kan nie gekoop word nie en sy waarheidsmoment kan nie sonder die voortdurende aanwending van wysheid bereik, of selfs begryp, word nie

Op hierdie wyse het daar voor ons 'n toneel ontvou van ewigdurende antieke waardes wat reeds by Sokrates en Plato verwoord is en wat die begrippe van geregtigheid, billikheid en waarheid met mekaar in verband gebring het. Hierdie begrippe is in die latere historiese ontwikkeling nog verder uitgebou en bestaan steeds as 'n deel van moderne waardestelsels soos dié wat tans in Suid-Afrika bestaan en teenswoordig belangrike aanwendings ervaar.

\section{Latere ontwikkeling van die geregtigheidsbegrip}

Van die Platoniese waardes hierbo beskryf, was dit veral die geregtigheidsbegrip wat aandag getrek het. Uit die gesprek oor geregtigheid by Plato, is dit ooglopend dat geregtigheid in al sy verskyningsvorms nie 'n uitvindsel van die twintigste eeu is nie en ook nie die produk is van die magtige menseregtekultuur wat veral gedurende die afgelope dekades die verbeelding van die regswêreld aangegryp het nie. Die oorsprong daarvan moet herlei word na die vroegste tye, of ten minste na die tyd van Sokrates, Plato en Aristoteles, van wanneer af dit 'n lang en oor die algemeen vrugbare ontwikkeling beleef het in die geskrifte en werksaamhede van tallose geslagte regsgeleerdes, politici, teoloë en filosowe uit alle wêrelddele. Ek lig kortliks enkeles onder hulle as voorbeelde van sodanige ontwikkeling uit.

\subsection{Cicero}

Die groot Romeinse juris, Marcus Tullius Cicero (106-43 v.C.), was 'n ywerige aanhanger van Plato en sy kardinale deugde, wat hy in Latyn weergegee het as sapientia (wysheid) of prudentia (verstandigheid), iustitia (geregtigheid), 
fortitudo (moed) en temperantia (matigheid of selfbeheersing). Dit was juis een van sy grootste bydraes tot die reg en die filosofie dat hy Griekse terminologie vir latere geslagte in Latyn verewig het (Van Zyl, 1991 a:28-29)

In sy traktaat oor die doelstellinge van goed en kwaad (De finibus bonorum et malorum) het Cicero geregtigheid ten nouste in verband gebring met etiese en morele waardes. Hy verwys juis (in De finibus 5.23.65) na geregtigheid as "die bedoeling om aan elk te gee wat hom toekom" (animi affectio suum cuique tribuens).

Elders (in De inventione 2.53.160) beskryf hy geregtigheid as "'n geestestoestand wat die gemeenskaplike voordeel handhaaf deur die waardigheid van alle mense te erken" (habitus animi communi utilitate conservata suam cuique tribuens dignitatem).

\subsection{Ulpianus}

'n Ander bekende Romeinse juris, naamlik Ulpianus, wat in die derde eeu na Christus geleef het, het geregtigheid omskryf as "die voortgesette en ewigdurende begeerte om aan elk sy eie reg te laat toekom" (Digesta 1.1.10 pr: Iustitia est constans et perpetua voluntas ius suum cuique tribuere). Die grondliggende beginsels van die reg was, volgens hom, "om eerbaar te lewe, om 'n ander nie te benadeel nie en om aan elk te gee wat hom toekom" (Digesta 1.1.10.1: Iuris praecepta sunt haec: honeste vivere, alterum non laedere, suum cuique tribuere)

In hierdie verband lê Ulpianus klem op die belangrikheid van die oorsprong van die begrip "reg" (ius), wat volgens hom uit geregtigheid (iustitia) afkomstig is. Dan haal hy goedkeurend aan die bekende omskrywing, afkomstig van die juris Celsus, van die reg (ius) as "die kuns van dit wat goed en billik is" (ars boni et aequi) (Digesta 1.1.1pr: Iuri operam daturum, prius nosse oportet, unde nomen iuris descendat; est autem a iustitia appellatum: nam ut eleganter Celsus definit, ius est ars boni et aequi).

\subsection{Thomas van Aquino}

Dit is hieruit duidelik dat die juriste van ouds geregtigheid beskou het as nie alleen 'n regsbegrip nie, maar ook bepaald as 'n begrip met moreel-etiese fasette. Dit verbaas 'n mens dus nie besonder dat Plato, Cicero en Ulpianus figureer in Thomas van Aquino (1225-1274) se Middeleeuse beskrywing van geregtigheid as "die geestesgesteldheid ingevolge waarvan iemand, met 'n voortgesette en ewigdurende begeerte, aan elk sy eie reg laat toekom" (Summa theologiae 2.2.58.1: ... justitia est habitus secundum quem aliquis constanti et perpetua voluntate jus suum unicuique tribuit). 


\subsection{Hugo Donellus}

In die Europese regsontwikkeling het die vermaarde Franse humanis, Hugues Doneau (Hugo Donellus) (1527-1591) die reg (jus) omskryf as "die kuns van dit wat billik en goed is en wat tot geregtigheid aanleiding gee" (Commentarii de jure civile 1.13.12: Jus est ars aequi et boni, est ars, ad justitiam ferens).

\subsection{Hugo de Groot}

Op soortgelyke wyse het daardie grootste onder die Romeins-Hollandse juriste, Huigh de Groot (Hugo Grotius) (1583-1645), gesê dat die regswetenskap (lurisprudentia) bekend is as "die kuns van dit wat goed en billik is" (De aequitate 2: ... iurisprudentia ars boni et aequi dicitur).

Elders doen hy aan die hand dat billikheid (aequitas) heel gepas en op sonderlinge wyse as "korrektiewe deug van die wil" (virtus voluntatis correctrix) dien in gevalle waar 'n wet (lex) as gevolg van sy algemeenheid defektief is (De aequitate 3: Proprie vero et singulariter aequitas est virtus voluntatis correctrix eius in quo lex deficit ob universalitatem). Die korrigerende werking van redelikheid en billikheid word omvattend bespreek deur Neels (1998:702-718); hy verwys (op p. 714) na die onderhawige teks as synde afkomstig uit De Groot se Prolegomena juri hollandico praemittenda 3.

\subsection{John Rawls}

Heelwat meer onlangs het die Amerikaanse filosoof, John Rawls, geregtigheid ("justice") beskryf as "the first virtue of social institutions, as truth is of systems of thought" (Rawls, 1972:3). Oor hierdie dictum merk Lourens du Plessis op dat dit gebaseer word op 'n lang tradisie van persepsies wat Rawls in twintigsteeeuse idioom weergee (Du Plessis, 1980:57).

\section{Antieke waardes in Suid-Afrikaanse konteks}

\subsection{Die geregtigheidsbegrip}

Die geregtigheidsbegrip het, in die nuwe Suid-Afrika, aansienlike veranderings ondergaan wat betref sy inhoud en omvang. Die primêre doel daarvan is egter nog steeds om die vreedsame en harmoniese samesyn van al sy mense te bewerkstellig in 'n gemeenskap waarin algemeen aanvaarde demokratiese waardes heers en waarin volle erkenning verleen word aan die bevordering van geregtigheid vir almal en aan die beskerming van fundamentele menseregte en vryhede. Hierdie doelstelling vind sy regmatige plek in die aanhef van die nuwe 
Grondwet (Wet 108 van 1966), wat deur die land se "vryverkose verteenwoordigers" aangeneem is ten einde

Die verdeeldheid van die verlede te heel en 'n samelewing gegrond op demokratiese waardes, maatskaplike geregtigheid en basiese menseregte te skep;

Die grondslag te lê vir 'n demokratiese en oop samelewing waarin regering gegrondves is op die wil van die bevolking en elke burger gelyk deur die reg beskerm word;

Die lewensgehalte van alle burgers te verhoog en die potensiaal van elke mens te ontsluit; en

'n Verenigde en demokratiese Suid-Afrika te bou wat sy regmatige plek as 'n soewereine staat in die gemeenskap van nasies kan inneem

\subsection{Die handves van menseregte}

Die oorgangsfase van ontwikkeling op politieke, maatskaplike en juridiese terrein in Suid-Afrika is die produk van 'n langdurige stryd om geregtigheid vir alle Suid-Afrikaners te bewerkstellig. Dit is in die besonder gesimboliseer deur die invoer van 'n menseregte-akte ("handves van menseregte") vir die eerste keer in die Suid-Afrikaanse regsgeskiedenis. Groot verantwoordelikhede word daardeur geskep vir sowel die uitvoerende as wetgewende gesag, maar dit is veral die regterlike gesag waarop die plig lê om geregtigheid te bewerkstellig in die daaglikse regsverkeer.

\section{Geregtigheid, billikheid en waarheid in die Grondwet}

\subsection{Demokratiese waardes}

Dat geregtigheid, billikheid en waarheid ten nouste gekoppel word in die nuwe konstitusionele bedeling, blyk telkens uit verskillende bepalings van die SuidAfrikaanse Grondwet. So, byvoorbeeld, kom dit by uitstek voor in die handves van regte in hoofstuk 2 van die Grondwet. Reeds in artikel 7(1) daarvan lees ons:

Hierdie Handves van Regte is ' $n$ hoeksteen van demokrasie in Suid-Afrika. Dit verskans die regte van alle mense in ons land en bevestig die demokratiese waardes van menswaardigheid, gelykheid en vryheid.

\subsection{Gelykheid en billikheid}

Die gelykheidsbeginsel word gekoppel aan billikheid in artikel 9, wat grotendeels draai om billike teenoor onbillike diskriminasie op die gebied van, enersyds, gelykheid voor die reg en, andersyds, die reg op gelyke beskerming en bevoordeling deur die reg (kyk die geleerde bespreking van "gelykberegtiging" deur Van der Vyver, 1998:368-399). Dit kan weer in verband gebring word met 
billike teenoor onbillike arbeidspraktyke in arbeidsverhoudinge, soos in artikel 23 gereël.

\subsection{Redelikheid en billikheid}

Op soortgelyke wyse word billikheid weer met die redelikheidskriterium verbind, soos in artikel 24, met verwysing na elke persoon se reg op 'n gesonde omgewing en die beskerming daarvan "deur redelike wetgewende en ander maatreëls" (artikel 24(b))

Onbillike diskriminasie het juis aanleiding gegee tot die omvattende bepalings oor eiendom in artikel 25, waarin geregtigheid (regverdigheid), billikheid en redelikheid met die openbare belang (die boni mores van weleer) gekoppel word.

Meer spesifiek op die gebied van onteiening word dit ten duidelikste gestel, in artikel 25(1), dat die ontneming van eiendom nie arbitrêr mag geskied nie en, in artikel 25(2), dat onteiening mag geskied slegs indien dit vir 'n openbare doel of in die openbare belang is. Daarbenewens moet dit, ingevolge artikel 25(3), onderhewig wees aan die betaling van vergoeding op 'n regverdige en billike grondslag, dit wil sê by wyse van 'n "billike ewewig" tussen die openbare belang en die belange van diegene wat deur die onteiening geraak word.

In hierdie verband word dit ook van die staat verwag om, ooreenkomstig artikel 25(5), "redelike wetgewende en ander maatreëls" te tref om burgers daartoe in staat te stel om "op 'n billike grondslag" toegang tot grond te kan verkry. Persone wat in die verlede besitsreg of eiendom ten opsigte van grond verloor het as gevolg van wette of praktyke wat rassediskriminasie meegebring het, is, ingevolge die bepalings van artikels $25(6)$ en (7), geregtig daarop om in hulle besit of eiendom van die relevante grond herstel te word, of om billike vergoeding in die plek daarvan te kry.

"Redelike wetgewende en ander maatreëls" moet, ooreenkomstig artikel 26(2), geneem word ten opsigte van die reg op toegang tot geskikte behuising ingevolge artikel 26(1). Sodanige maatreëls moet eweneens ooreenkomstig artikel 27(2) geneem word met betrekking tot die reg op gesondheidsorg, voedsel, water en maatskaplike sekerheid ingevolge artikel 27(1). Ook met betrekking tot die reg op basiese onderwys bepaal artikel 29(1)(b) dat "redelike maatreëls" deur die staat getref moet word op die grondslag van wat billik en doenlik is en met die oogmerk om, inter alia, enige vorm van rassediskriminasie uit te skakel.

Artikel 33(1) gee aan elkeen "die reg op administratiewe optrede wat regmatig, redelik en prosedureel billik is", terwyl artikels 34 en 35(3) waarborg dat elkeen op "'n billike openbare verhoor" geregtig is. 
Van belang is die beperkingsklousule vervat in artikel 36(1), wat bepaal dat die regte in die handves vervat alleenlik kragtens "'n algemeen geldende regsvoorskrif" beperk mag word, en dan slegs vir sover die beperking "redelik en regverdigbaar is in 'n oop en demokratiese samelewing gebaseer op menswaardigheid, gelykheid en vryheid". Dit strook met die bepalings van artikel 39 ten opsigte van die uitleg van die handves, waarin dit van die judisiële beampte geverg word dat hy of sy "die waardes wat 'n oop en demokratiese samelewing gebaseer op menswaardigheid, gelykheid en vryheid ten grondslag lê", moet bevorder.

\subsection{Regspleging}

Hoofstuk 8 van die Grondwet handel oor die howe en regspleging. Artikel 165(2) beskryf die howe as "onafhanklik en onderworpe slegs aan die Grondwet en die reg, wat hulle onpartydig en sonder vrees, begunstiging of vooroordeel moet toepas". Artikel 165(4) bepaal weer dat "staatsorgane" die howe moet bystaan en beskerm, deur middel van wetgewende en ander middels, "ten einde die onafhanklikheid, onpartydigheid, waardigheid, toeganklikheid en doeltreffendheid van die howe te verseker". Howe het die bevoegdheid, ingevolge artikel 172(1)(b), om enige bevel te gee "wat regverdig en billik is". Daarbenewens het die Konstitusionele Hof, die Hoogste Hof van Appèl en die Hooggeregshowe, kragtens artikel 173, "die inherente bevoegdheid om, met inagneming van die belang van geregtigheid, hul eie proses te beskerm en te reel en die gemene reg te ontwikkel".

\subsection{Staatsinstellings}

Daar is ' $n$ hele aantal staatsinstellings wat deur die Grondwet daargestel is met die oog daarop om, sover moontlik, geregtigheid, billikheid en waarheid in die openbare lewe te handhaaf. Ons dink hier veral aan die Openbare Beskermer (voorheen bekend as die Ombudsman) en die Menseregtekommissie, wat hulle bevoegdhede ontleen aan artikels 182-183 en 184-186 onderskeidelik. Die Openbare Beskermer ondersoek onbehoorlike optrede in staatsake of in die openbare administrasie, terwyl die Menseregtekommissie ingestel is op die handhawing, beskerming en bevordering van menseregte.

Wat betref die openbare administrasie as sodanig, omvat artikel 195 die "basiese waardes en beginsels" waaraan dit onderhewig gestel word. Allereers word dit "beheers deur die demokratiese waardes en beginsels wat in die Grondwet verskans is", met inbegrip daarvan dat sy dienste "onpartydig, regverdig, op billike grondslag en sonder vooroordeel" gelewer moet word (artikel 195(1)(d)).

Binne die openbare administrasie funksioneer die staatsdiens (artikel 197) en die allerbelangrike Staatsdienskommissie (artikel 196) wat, net soos die howe, onafhanklik en onpartydig moet wees, en voorts "sonder vrees, begunstiging of 
vooroordeel" sy bevoegdhede moet uitoefen en sy funksies moet verrig (artikel 196(2)). Die staatsdiens word bygestaan en beskerm deur ander staatsorgane ten einde sy "onafhanklikheid, onpartydigheid, waardigheid en doeltreffendheid" te verseker (artikel 196(3)).

\subsection{Waarheid en versoening}

Die waarheidsbegrip in hierdie nuwe konstitusionele bedeling het 'n toonaangewende rol gespeel in die bedrywighede van die Kommissie vir Waarheid en Versoening, wat deur die Wet op Bevordering van Nasionale Eenheid en Versoening 34/1995 in die lewe geroep is. Dit het eers heel onlangs sy werksaamhede afgesluit en daaroor verslag gedoen het. Hoewel daar aanvanklik heelwat teenkanting teen die Kommissie was, het dit spoedig geblyk dat die openbare ondersoeke en gepaardgaande amnestieverhore 'n waardevolle rol kon speel as katalisator in die versoeningsproses wat in Suid-Afrika so nodig was en nog steeds is. Die volle waarheid is sekerlik nie ontbloot nie, maar dit was genoeg om vir baie Suid-Afrikaners as stimulus te dien om daadwerklike pogings aan te wend om die verlede in sy korrekte konteks te plaas en om in alle opsigte 'n nuwe Suid-Afrika daar te stel waarin geregtigheid en billikheid ewigdurend gesag sou voer.

\section{Slotgedagtes}

Uit hierdie ondersoek van die Grondwet kom dit na vore dat geregtigheid, billikheid, redelikheid en die strewe na waarheid die bepalings van die Grondwet en die bedrywighede van die regspleging en staatsinstellings grotendeels onderlê. In baie opsigte is dit die begrippe en beginsels waarom die nuwe Suid-Afrika draai. Dit moet egter nie uit die oog verloor word nie dat, hoe oorspronklik Suid-Afrika ook al in sy nuwe gedaante mag wees, hierdie begrippe en beginsels spreekwoordelik so oud is as die berge. In die bespreking van Plato en sy leermeester, Sokrates, het geregtigheid as een van die kardinale of hoofdeugde 'n fundamenteel belangrike rol gespeel. Dit het in Plato se werke reeds vasgestaan dat geregtigheid nie 'n bloot juridiese begrip is nie, maar gepaard gaan met die ander hoofdeugde, te wete wysheid (waarby ingesluit is verstandigheid), moed of dapperheid en matigheid of selfbeheersing. Hierdie is eienskappe wat van leiers deur die eeue heen verwag is en wat nog steeds van hulle verwag word, of hulle nou in die politiek is, op die regbank of waar ook al. 'n Deugsame leier of regter wat hierdie eienskappe openbaar in die uitvoer van sy funksies, moet desnoods by die waarheid uitkom. Terselfdertyd sal hy geregtigheid laat geskied in die gees van dit wat billik en redelik is onder die omstandighede en sal hy eweneens die openbare belang bevredig dat hy sy funksies na behore uitvoer. Wanneer hy dit doen, hoe byderwets sy optrede ook al mag voorkom, sal hy besig wees om, binne 'n Suid-Afrikaanse konteks, antieke waardes, wat sover teruggaan as die tydperk van die filosoof Plato, toe te pas. 


\section{Literatuurlys}

ARNHEIM, M.T.W. 1977. Aristocracy in Greek society. London : Thames \& Hudson. DU PLESSIS, L.M. 1980 Reg, geregtigheid en menseregte Obiter. 51-85.

FIELD, G.C. 1913. Socrates and Plato. Oxford : Oxford University Press.

JONES, J.W. 1956. The law and legal theory of the Greeks: An introduction. Oxford : Oxford University Press.

NEELS, J.L. 1998. Regsekerheid en die korrigerende werking van redelikheid en billikheid (deel 1). Tydskrif vir die Suid-Afrikaanse Reg. 702-718.

RAWLS, J. 1972. A theory of justice. Oxford : Oxford University Press

SHOREY, P. 1969. Plato. The Republic. Vol. 1. Cambridge, Massachusetts : Harvard University Press / London : Willie Heinemann.

VAN DER VYVER JD. 1998. Gelykberegtiging. Tydskrif vir Hedendaagse RomeinsHollandse Reg, 61:367-399.

VAN ZYL, D.H. 1991a. Justice and equity in Cicero: A critical evaluation in contextual perspective. Pretoria : Academica

VAN ZYL, D.H. 199lb. Justice and equity in Greek and Roman legal thought. Pretoria Academica. 